\title{
THE OCCURRENCE OF CERTAIN ELEMENTS IN MILK AND SOME DAIRY PRODUCTS 2 -EFFECT OF MILK PROCESSING ON THE DISTRIBUTION OF ZN, FE, CD AND PB IN THE RESULTANT PRODUCTS
}

\author{
MOHRAN, M.A. ${ }^{1}$, S.M. EL-GENDY ${ }^{1}$, A.I. SAID ${ }^{2}$ AND T.H. MOHAMED ${ }^{2}$
}

1. Dairy Department, Faculty of Agriculture, Assiut University, Assiut

2. Special Food Department - Food Technology Research Institute. ARC, Giza

(Manuscript received 2 August 2010)

\begin{abstract}
The effect of some milk processes on the distribution of $\mathrm{Zn}, \mathrm{Fe}$, $\mathrm{Cd}$ and $\mathrm{Pb}$ in the resultant products had been investigated. The levels of these elements in used raw milk and the obtained products were estimated (ppm). It was found that a little variation in the levels of $\mathrm{Zn}, \mathrm{Fe}, \mathrm{Cd}$ and $\mathrm{Pb}$ in yoghurt as compared with used milk. The values of these metals in yoghurt were 91.89, 89.83, 97.97 and $103 \%$ for $\mathrm{Zn}, \mathrm{Fe}, \mathrm{Cd}$ and $\mathrm{Pb}$ as compared with their levels in raw milk. The distribution of respective elements during the separation of raw milk into cream and skim milk were 6.07 and $91.54 \%$ of $\mathrm{Zn}, 6.12$ and $90.28 \%$ of $\mathrm{Fe}, 3.39$ and $95.21 \%$ of $\mathrm{Cd}$ and 3.37 and $94.72 \%$ of $\mathrm{Pb}$ respectively.

The churning process of cream into butter and butter milk reduced the respect elements in resultant butter. The obtained butter contained 37.47, 41.95, 43.7 and $42.20 \%$ of $\mathrm{Zn}, \mathrm{Fe}, \mathrm{Cd}$ and $\mathrm{Pb}$ of the initial elements in used cream respectively, while, butter milk contained $62.55,58.28,55.82$ and $56.67 \%$ of these metals in the same respect. The levels of these elements in butter as compared with used raw milk were $2.22,2.55,1.48$ and $1.42 \%$ of $\mathrm{Zn}, \mathrm{Fe}, \mathrm{Cd}$ and $\mathrm{Pb}$ respectively. The resultant samna contained only $1.09,1.51,1.07$ and $0.98 \%$ of $\mathrm{Zn}, \mathrm{Fe}, \mathrm{Cd}$ and $\mathrm{Pb}$ levels of the initial elements of raw milk.

The percentage levels of $\mathrm{Zn}, \mathrm{Fe}, \mathrm{Cd}$ and $\mathrm{Pb}$ in curds of whole and skimed milk as compared with the initial materials were 83.70 \& 85.02; 83.35 \& 88.42; $70.97 \& 75.47$ and $78.22 \& 79.91 \%$ respectively. The resultant whey contained only $16.65 \& 15.03$; 16.94 \& 14.69; 28.98 \& 24.87 and 19.78 \& $18.94 \%$.
\end{abstract}

\section{INTRODUCTION}

As early as 1968 , The International Dairy Federation (IDF) issued information on heavy metals contamination of milk and dairy products followed by further publications. Heavy metals make up on of the most important groups in food supply (Protasowicki, 1992). 
In recent years, risks of heavy metals that may pollute different foods have been receiving increased attention. Heavy metals contamination of milk is now considered to be a greater problem than that of pesticides. Newer analytical techniques with higher sensitivity have been employed to determine the levels of these elements in dairy products. (IDF, 1992).

Kolodkin, et al (1979) found that cream $35 \%$ fat contained $15 \%$ of the $\mathrm{Pb}$ as initial milk, yoghurt contained Fe, 98.87 Zn 99.2 and Pb 100\% as initials (Abou-Arab 1991).

Separation of whole milk into cream and skim milk reduced the heavy metal potential in the resultant cream and the process was more effective in cows than buffalo's milk (El-Awamry, 1994). Churning of buffalo's cream into butter reduced the heavy metals potential in the obtained butter with about $70 \%$ of cream content, while the reduction as compared with milk content was $90 \%$. The calculation of heavy metals content of the resultant samna compared with those of raw milk showed that the reduction value was about 95\%. (El-Awamry, 1994).

It was found that the concentration of $\mathrm{Pb}$ in cheese made from lead contaminated milk was about six times that in original milk Marletta and Favretto (1983)

During the manufacture of Domiati cheese, Metwally (1993) found that $49.3 \%$ of $\mathrm{Pb}$ in cheese and $50.7 \%$ in whey.

The heavy metal concentration decreased during pickling of Domiati cheese (Abou El-Enein 1998).

The incidence of $\mathrm{Zn}, \mathrm{Fe}, \mathrm{Cd}$ and $\mathrm{Pb}$ in raw milk as well as some dairy products had been investigated recently (Mohran, et al 2010).

The aim of present work was to study the effect of some milk processes on distribution of $\mathrm{Zn}, \mathrm{Fe}, \mathrm{Cd}$ and $\mathrm{Pb}$ in the resultant products.

\section{MATERIALS AND METHODS}

\section{1- Materials}

- Raw bulk cow's milk was obtained from the herd of the Faculty of Agriculture, Assiut University.

-Yoghurt starter was obtained from (MIRCEN) Microbial Resources Center, Faulty of Agriculture, Ain Shams University.

- Rennet powder was obtained from Ch. Hansen's Laboratories.

\section{2- Methods of Analysis}

The incidence of $\mathrm{Zn}, \mathrm{Fe}, \mathrm{Cd}$ and $\mathrm{Pb}$ in raw milk, cream , skim milk, butter, butter milk, samna, morta, yoghurt, white soft cheese curd and its whey as will as 
Kareish cheese curd and its whey had been estimated ( $\mathrm{ppm}$ ) according to the method described by James (1995) using atomic absorption spectrophotometer (AA-630-02 Shimadzu-Japan).

The obtained values (ppm) were multiplied by the quantity of product to give the total amounts of respective elements and calculated its distribution.

\section{3- Experimental procedure}

A total of $25 \mathrm{Kg}$ of raw milk were divided as follows:

a) One $\mathrm{Kg}$ was heated at $90{ }^{\circ} \mathrm{C}$ for $30 \mathrm{~min}$ and used for making yoghurt using yoghurt starter supplied from (MIRCEN).

b) $14 \mathrm{Kg}$ milk was warmed at $35^{\circ} \mathrm{C}$ and separated to cream $(1.0 \mathrm{~kg})$ and skim milk (13.0kg). Resultant cream was churned into butter and butter milk (500g. of each). The obtained butter was converted to samna by boiling which gave $375 \mathrm{~g}$ samna and $100 \mathrm{~g}$ of morta.

c) $10 \mathrm{~kg}$ milk was heated at $70^{\circ} \mathrm{C}$ for $2-3$ min, cooling to $35^{\circ} \mathrm{C}$ and unsalted milk was renneted to make white soft cheese according to El-Gendy. (1970) ( $2 \mathrm{~kg}$ of cheese and $8 \mathrm{~kg}$ of whey). Defatted milk curd also was obtained from the unsalted forgoing skim milk to give $2.2 \mathrm{~kg}$ curd and $10.8 \mathrm{~kg}$ whey.

\section{RESULTS AND DISCUSSION}

The distribution of $\mathrm{Zn}, \mathrm{Fe}, \mathrm{Cd}$ and $\mathrm{Pb}$ in some dairy products as affected by manufacture processes, are shown in Fig.1-5.

\section{Effect of fermentation during manufacture of yoghurt}

Fig (1) illustrate the distribution of the tested trace elements in milk and yoghurt. It could be observed that little variation in the quantities of $\mathrm{Zn}, \mathrm{Fe}, \mathrm{Cd}$ and $\mathrm{Pb}$ between resultant yoghurt and used milk. The content of $\mathrm{Zn}$ in the obtained yoghurt was 3.83 ppm which represent $(91.89 \%)$ of initial raw milk. The Fe content was lower than that of $\mathrm{Zn}(1.87 \mathrm{ppm})$ which represents about (89.83\% of initial milk). Approximately no differences were found in the cases of $\mathrm{Cd}$ and $\mathrm{Pb}$. Resultant product contained about $97.97 \%$ of $\mathrm{Cd}$ and $103.68 \%$ of $\mathrm{Pb}$ as compared with their levels in used milk. The same finding was reported by Abou-Arab (1991) and El-Awamry (1994).

\section{Effect of processes used for manufacture of milk fat products}

Fig (2) represents the distribution of respective elements during the separation of raw milk into cream and skim milk. It was found that $6.07,6.12,3.39$ and $3.37 \%$ of $\mathrm{Zn}, \mathrm{Fe}, \mathrm{Cd}$ and $\mathrm{Pb}$ of initial quantities in raw milk are separated with cream, while, skim milk was found to contain $91.54,90.28,95.21$ and $94.72 \%$ of 
respective metals. From the foregoing results it could be observed that more than $90 \%$ of pollutant elements separated with skim milk.

This finding may be due either to the binding of these elements with caseins or to their solubility in milk serum. Roh (1975) reported that $96 \%$ of $\mathrm{Cd}$ in whole milk was associated with the skim milk. The obtained results are inagreement with Mathur and Roy (1978) who stated that $90.4 \%$ of $\mathrm{Zn}$ in whole buffalo's milk was in skim milk. The distribution of $\mathrm{Pb}$ in skim milk and cream was reported also by Kolodkin, et. al (1979) who found that $15 \%$ of $\mathrm{Pb}$ as initial milk were detected in cream fraction . ElAwamry(1994) concluded that separation processes reduce the heavy metals potential in the resultant cream.

The manufacture of butter from cream showed that the churning process reduced the respect elements pollution in the resultant butter. As shown in Fig (3), the obtained butter contained 37.47, 41.95, 43.7 and $42.20 \%$ of $\mathrm{Zn}, \mathrm{Fe}, \mathrm{Cd}$ and $\mathrm{Pb}$, found in used cream respectively. On the other hand butter milk was found to contain the great portion of these metals compared with the butter. The percentages of the removed metals in butter milk were 62.55, 58.28, 55.82 and $56.67 \mathrm{Of} \mathrm{Zn}, \mathrm{Fe}, \mathrm{Cd}$ and $\mathrm{Pb}$ respectively. The distribution of investigated metals between butter and butter milk was in agreement with that reported by Abou-Arab (1991). El-Awamry (1994) reported also that the churning of cream into butter reduced the heavy metal potential in obtained butter with 68.5, 73.1, 65.7 and 75.0\%for $\mathrm{Fe}, \mathrm{Cd}, \mathrm{Zn}$ and $\mathrm{Pb}$, respectively, as compared with the quantities of these elements in used cream.

If the percentage levels of these elements in butter are calculated as compared with that of raw milk, higher reductions of the content of these elements were found. The respective percent of these elements levels are 2.22, 2.55, 1.48 and $1.42 \%$ for $\mathrm{Zn}, \mathrm{Fe}, \mathrm{Cd}$ and $\mathrm{Pb}$ respectively.

The conversation of butter to samna showed some variation in the contents of these elements in the obtained products (Fig 4). $\mathrm{Zn}$ is distributed between samna and murta with the ratio of approximately 49.84 and $50.23 \%$. On the other hand, samna contained $59.06,68.42$ and $69.23 \%$ of $\mathrm{Fe}, \mathrm{Cd}$ and $\mathrm{Pb}$, respectively and murta found to be contained, $30.87,36.84$ and $38.46 \%$ of these metals, in the same respect.

Although a high ratio of respective elements are transferred from butter to samna, samna contained only 1.09, 1.51, 1.07 and $0.98 \%$ of $\mathrm{Zn}, \mathrm{Fe}, \mathrm{Cd}$ and $\mathrm{Pb}$ found in initial raw milk. From the obtained results it could be concluded that the sequences of processing of raw milk led to reduction the pollution of these elements in fat milk products. Nearly the same findings were reported by Roh (1975), Abou-Arab (1991) Metwally (1993) and El-Awamry (1994). 


\section{3- Effect of milk coagulation on the distribution of $\mathrm{Zn}, \mathrm{Fe}, \mathrm{Cd}$ and $\mathrm{Pb}$ in resultant curd and whey}

The quantities of $\mathrm{Zn}, \mathrm{Fe}, \mathrm{Cd}$ and $\mathrm{Pb}$ in the curd obtained after the coagulation of $10 \mathrm{~kg}$ cow's milk were34.85, 8.56, 3.08 and $2.55 \mathrm{mg}$ respectively. These amounts represented $83.70,83.35,70.97$ and $78.22 \%$ of the initial levels found in used milk. Fig (5a) showed also that 16.65, 16.94, 28.94 and $19.78 \%$ of $\mathrm{Zn}, \mathrm{Fe}, \mathrm{Cd}$ and $\mathrm{Pb}$ amounts respectively as compared with the initial quantities in raw milk were removed in whey.

Rennet coagulation of skim milk had been carried out to examine the distribution the investigated elements in the obtained curd and whey. This curd showed approximately the same observations. From Fig. (5b), the resultant curd found to contain 45.42, 22.50, 4.37 and $3.46 \mathrm{mg}$ of $\mathrm{Zn}, \mathrm{Fe}, \mathrm{Cd}$ and $\mathrm{Pb}$ respectively. These levels represented $85.02,88.42,75.47$ and $79.91 \%$ of that polluted the used skim milk respectively. It is evident from Fig. (5b) also the partial removal of investigated metals with whey. The drainage whey found to contain 15.03, 14.69, 24.87 and $18.94 \%$ of $\mathrm{Zn}, \mathrm{Fe}, \mathrm{Cd}$ and $\mathrm{Pb}$ respectively found in skim milk.

The concentration of above elements in either full cream milk or skim milk curds may be attributed to that these elements bound strongly with certain casein components ( $a_{\mathrm{s}^{-}}, \mathrm{a}_{\mathrm{s} 2^{-}}, \beta$ - and k-caseins) and /or to casein micelles. The partial resolution of respective elements in whey was reported also by Mathur and Roy (1978) and Zidan et al. (1994). On the other hand the retentive values of these elements in rennet curd of both full cream milk and skim milk are higher than that reported by El-Awamry (1994) for both Domiati and Kareish cheese. 


\section{Fig (1) Distribution of certain trace elements in milk during manufacture of yoghurt.}

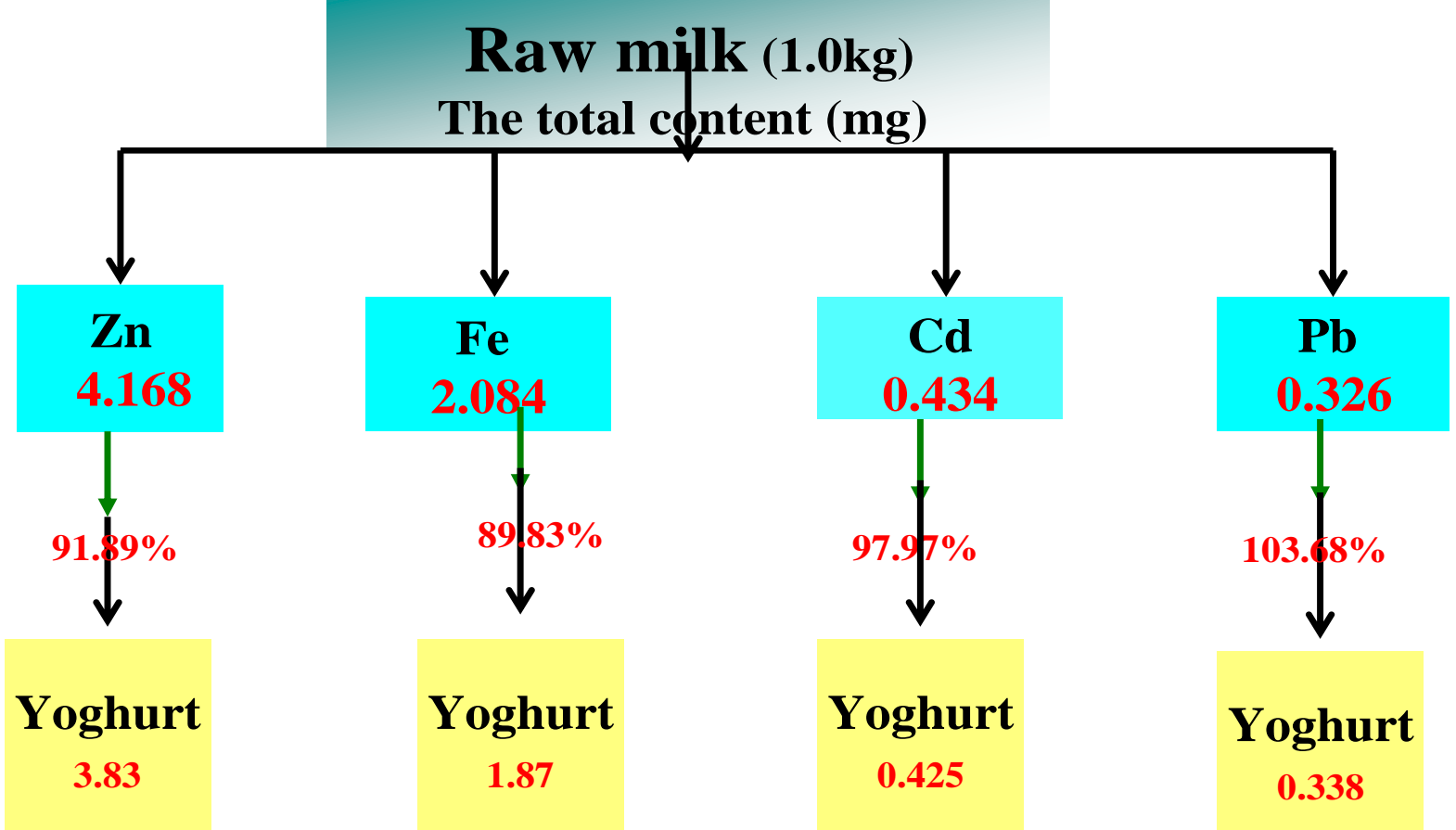




\section{Fig (2) Distribution of certain trace elements} in milk and resultant products during separation process.

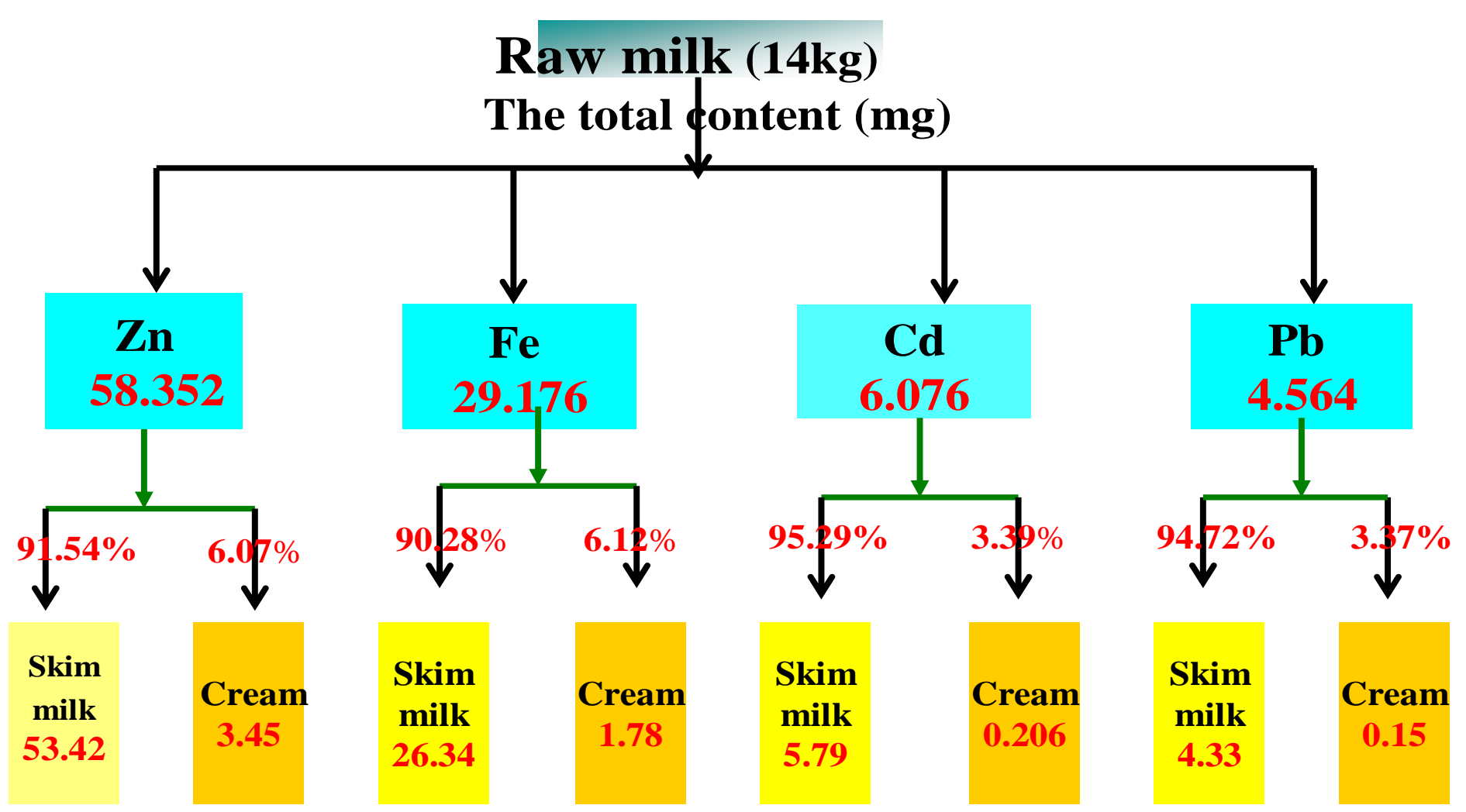




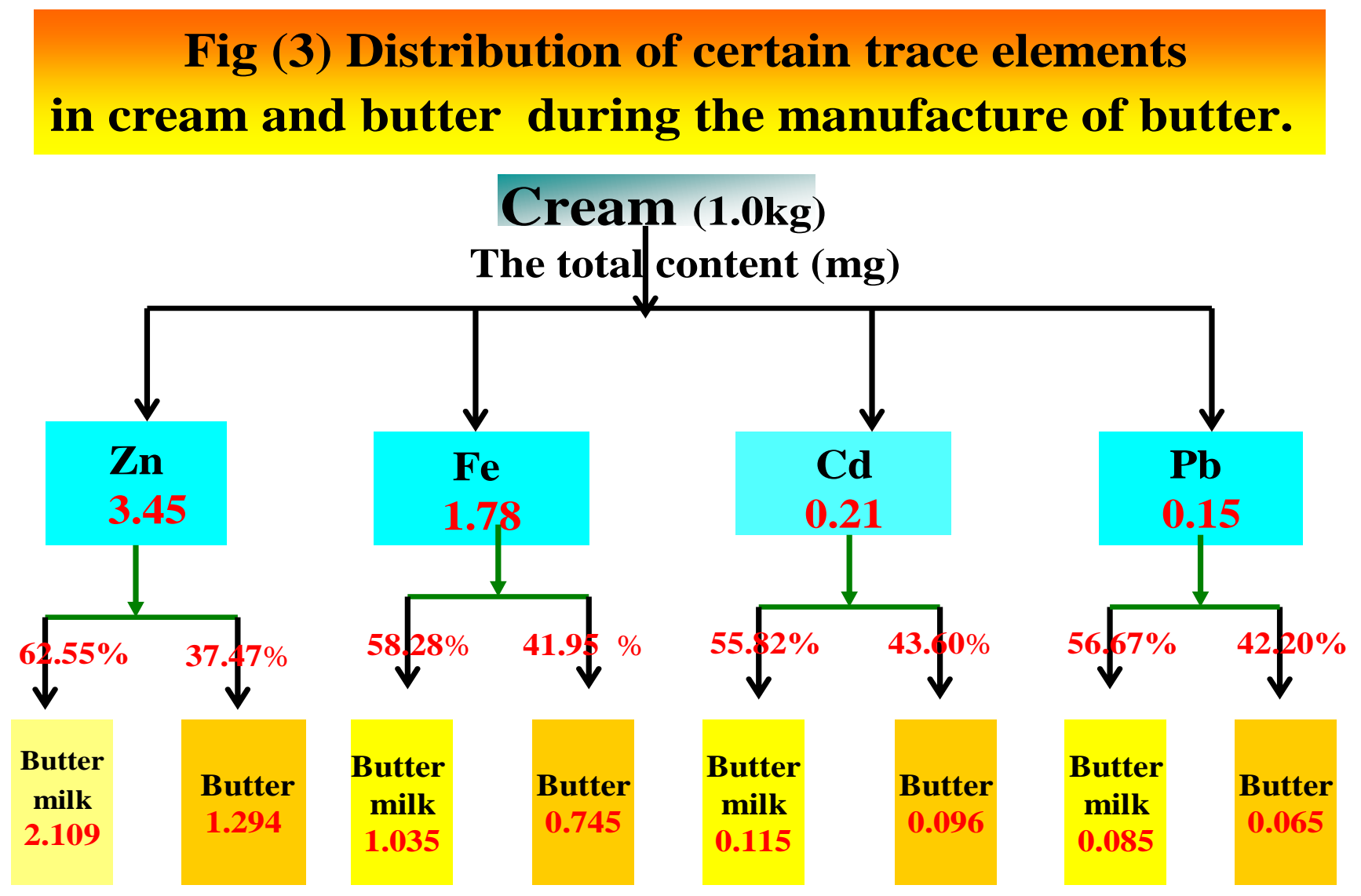




\section{Fig (4) Distribution of certain trace elements}

in butter and samna during the manufacture of samna.

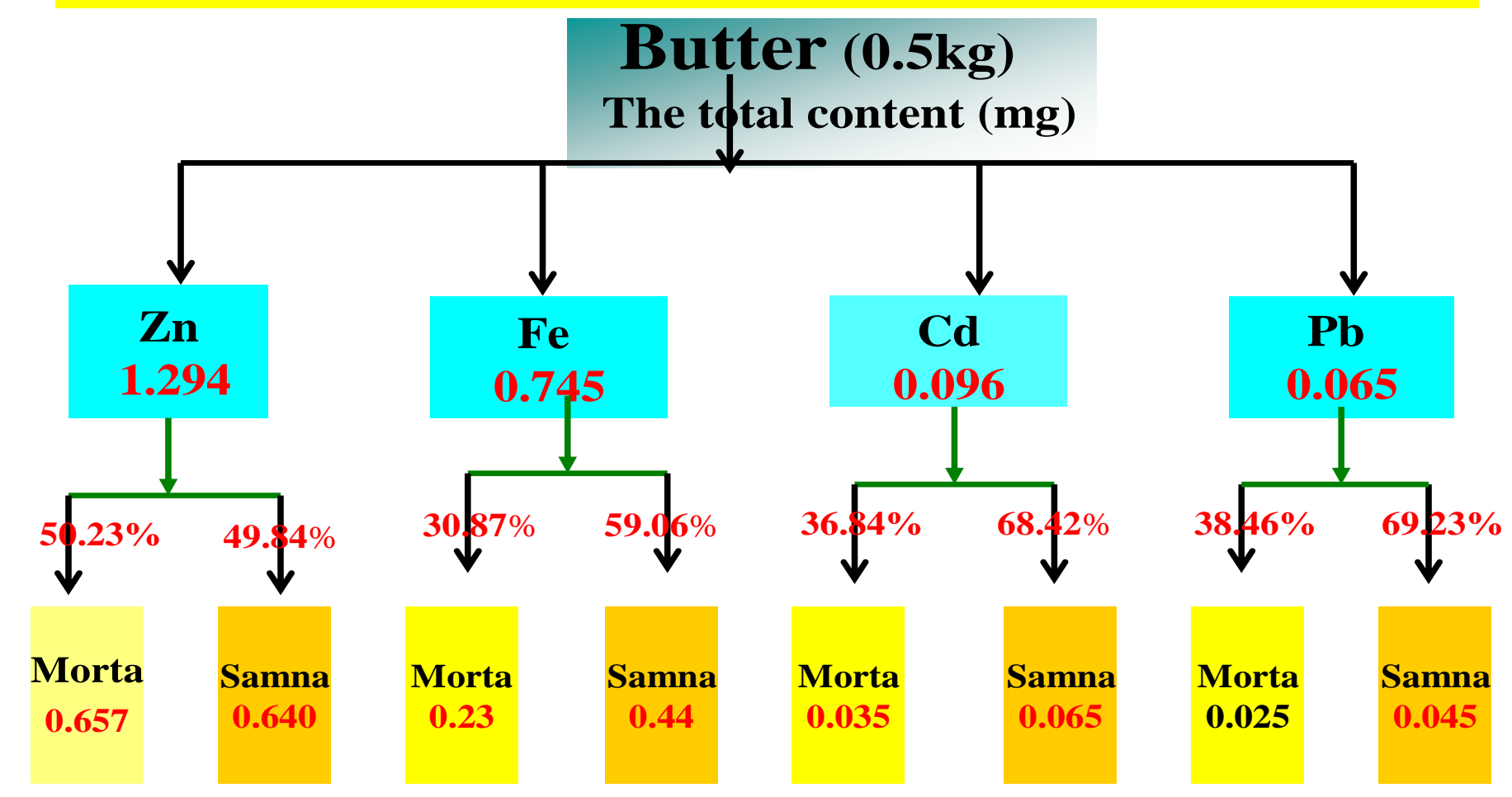




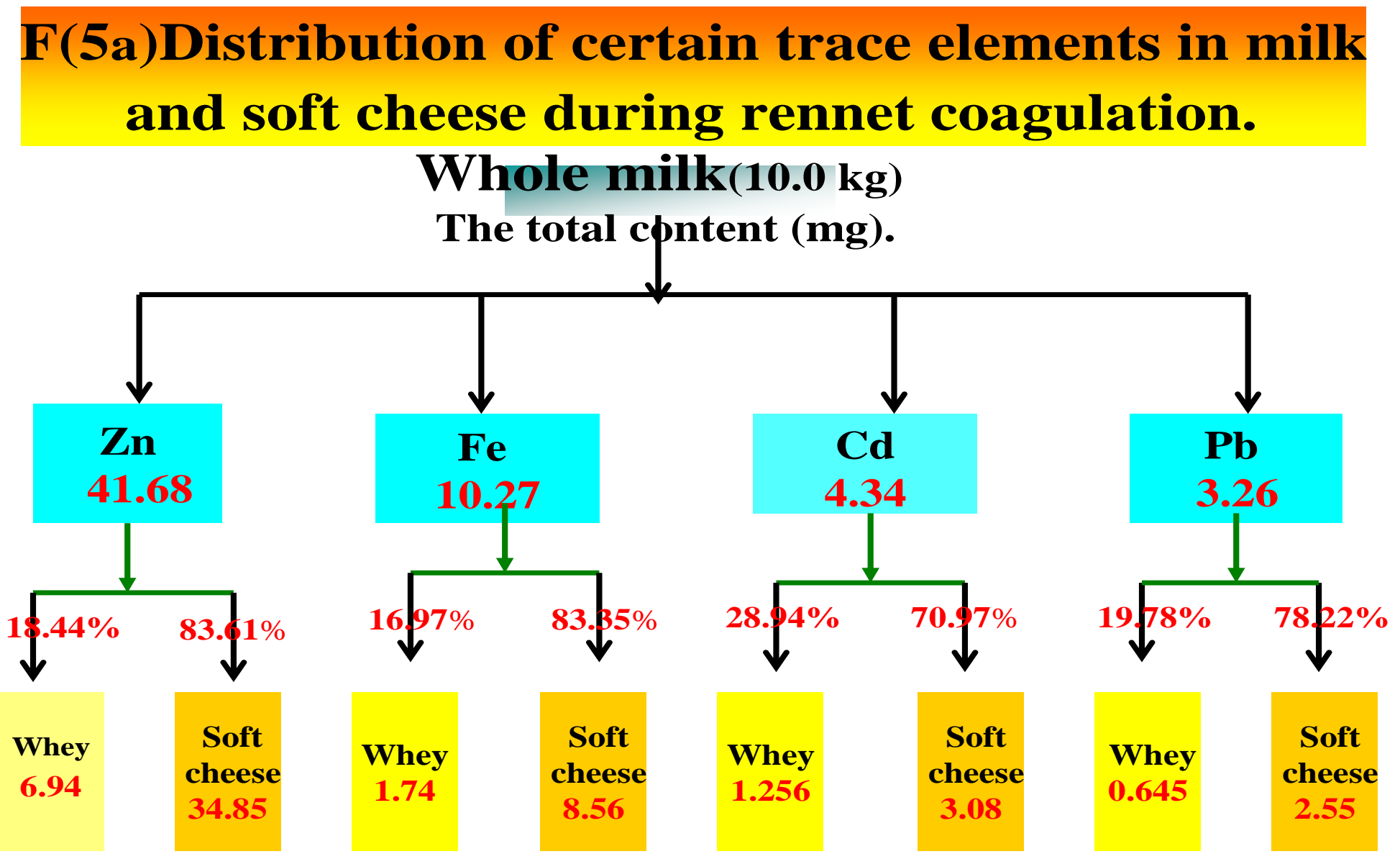




\section{F(5b)Distribution of certain trace elements in curd} and whey prepared by rennet coagulation of skim milk .

Skim milk (13.0kg)

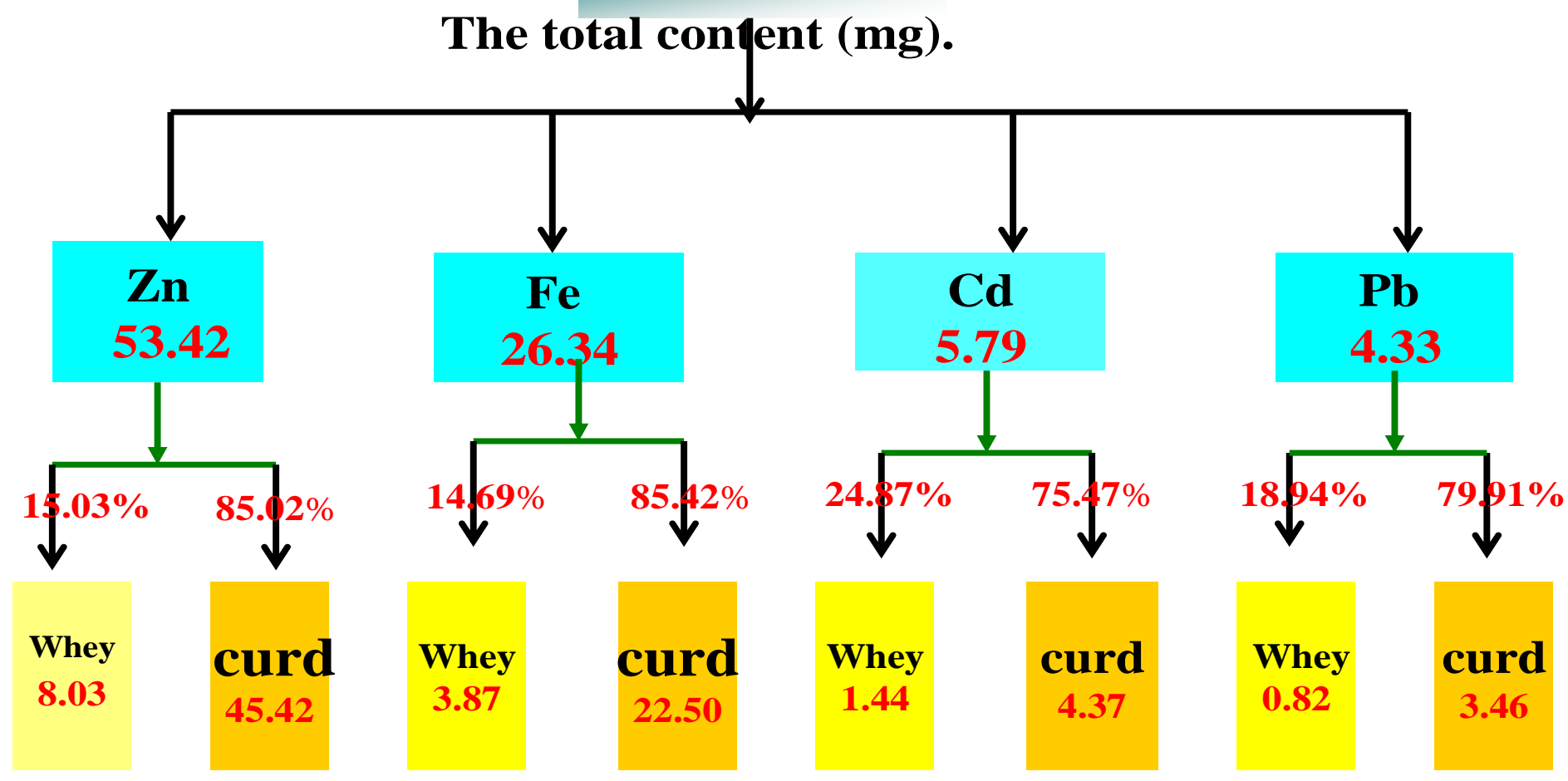




\section{REFERENCES}

1. Abou-Arab, A.A. 1991. Microbiological and compositional quality of dairy products in relation to some pollutants. Ph.D. Thesis Fac.Agric.,Ain Shams Univ., Cairo, Egypt.

2. Abou El-Enein, K.A.M. 1998. Studies on the contamination of Domiati cheese with some heavy metals. M.Sc. Thesis, in Environmental Science, Institute of Environmental Studies and Researches., Ain Shams University, Cairo, Egypt.

3. El-Awamry, Z.K. 1994. Reduction of the adverse effects of some chemical pollutant of milk in Egypt. Ph.D. Thesis. Institute of Environmental and Research. Ain Shams Univ., Cairo, Egypt.

4. El-Gendy, S.M. 1970. Studies on the influence of some additives on the chemical and bacteriological changes in cheese. Ph.D. Thesis, Fac. of Agriculture, Assiut University.

5. International Dairy Federation, IDF. 1992. trace elements in milk and milk products. Bulletin of the International Dairy Federation. No.278,88pp.

6. James, C.S. 1995. Analytical Chemistry of Foods. Blackie Academic\& Professional. London .England.

7. Kolodkin, A.M., E.Y.A. Ogneva, V.N. Elizareva and V.R. Ognev. 1979. Distribution of trace elements in milk and its constituents. Pishchevaya Teknol. 1:16.

8. Marletta, G.P. and L.G. Favretto. 1983. Preliminary investigation on the balance of lead and cadmium content in milk and its by-products. Zeitschrift fur Lebensmillel Untersuchung und Forschung. 176:32-35.

9. Mathur, O.N. and N.K. Roy. 1978. Studies on trace minerals in buffaloes, milk. II. Iron, Zinc, Sulphur and Boron. In XX International Dairy Congress Vol.E. : 50-51.

10. Metwally, M.M.K. 1993. Distribution of added lead to milk in some dairy products. Bull. Suez Canal Univ, Appl. Sci. Vol. 2. pp. 303-309.

11. Mohran, M.A. , S.M. El-Gendy, A.I. Said and T.H. Mohamed. 2010. The occurrence of certain elements in milk and some dairy products 1 -The levels of $\mathrm{Zn}, \mathrm{Fe}, \mathrm{Cd}$ and $\mathrm{Pb}$ in raw milk and some dairy products. Represented in the $5^{\text {th }}$ Scientific Conference of Agriculture Science. Fac. Agr. Assiut Uni. 10-17 October 2010. (15-27).

12. Protasowicki,M. 1992. Heavy metals content in the selected food. $3^{\text {rd }}$ World Congress, Food born infection and intoxication,16-19,June, Berlin.

13. Roh, J.K. 1975. Distribution and removal of selected heavy metals from milk. Dissertation abstracts International, B 35:4936.

14. Zidan, Z.H., A.E. Fayed, A.A. AbouArab and S.A. El Nockrashy. 1994. Monitoring some contaminants during the manufacture of some conventional dairy products. Egyptian J. Dairy Sci., 22:19-29. 
2- تأثير بعض المعاملات التكنولوجية للبن على محتوى المنتجات المتحصل عليها من عناصر الزتكك و الحديد و الكادميوم و الرصاص.

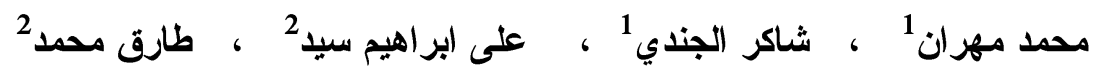

$$
\begin{aligned}
& \text {, } \\
& \text { r -قسم الاغنية الخاصة - معرة بحوث تكنولوجيا الاغذية - مركز البحوث الزراعية الزية }
\end{aligned}
$$

تم دراسة تأثير المعاملات التكنولوجية للبن على محتوى المنتجات المتحصل عليها من

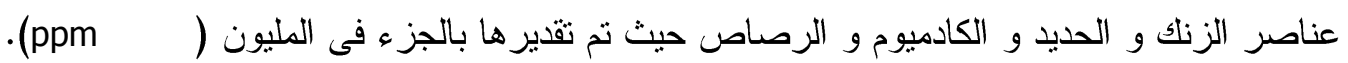

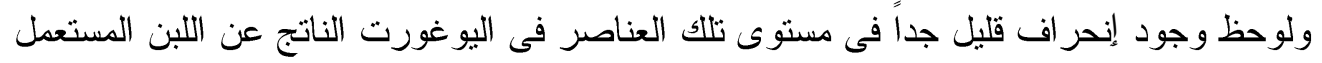

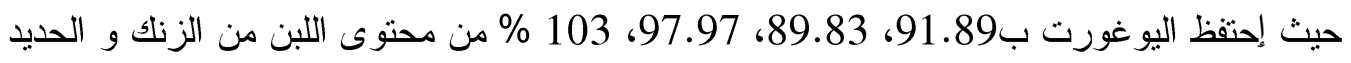

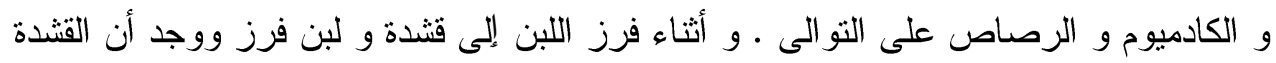

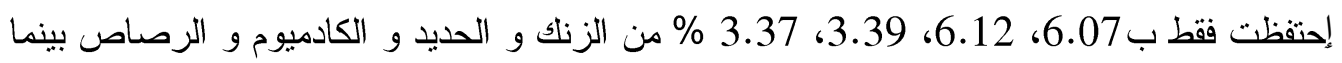

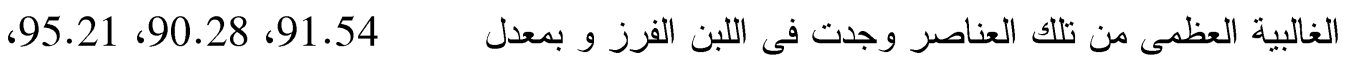
94.72 \% على نفس النزتيب .

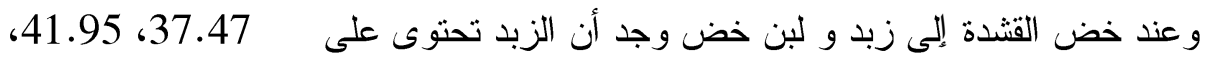

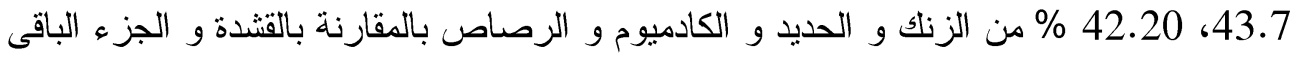

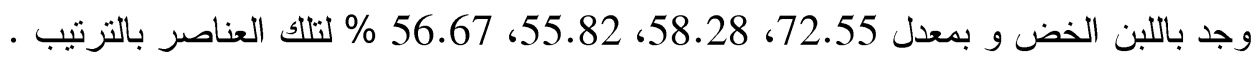

و عند مقارنة محتويات الزبد من نلك العناصر بما يحتوية اللبن الخام المستعمل فى

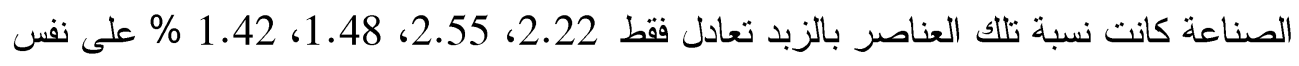

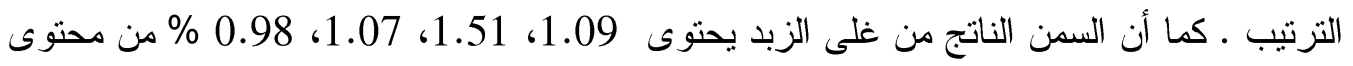

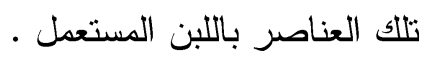

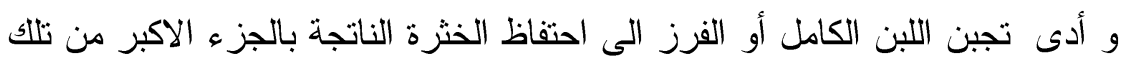

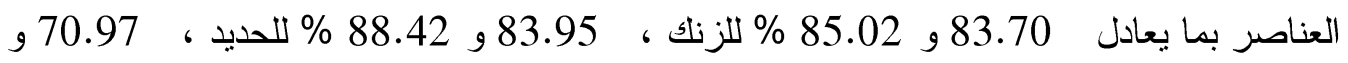
75.47 \% للكادميوم و 78.22 و 79.91 \% 85.72 \% للرصاص لكل من خثرة اللبن الكامل و اللبن الفرز على التو الى و الباقى وجد فى الثرش الناتج من كل منهما. 